\title{
Extension of the Storage Period of Platelet Concentrates in Germany to 5 Days by Bacterial Testing: Is it Worth the Effort?
}

\author{
Tanja Vollmer Dennis Hinse Jürgen Diekmann Cornelius Knabbe \\ Jens Dreier \\ Herz- und Diabeteszentrum Nordrhein-Westfalen, Institut für Laboratoriums- und Transfusionsmedizin, \\ Universitätsklinik der Ruhr-Universität Bochum, Bad Oeynhausen, Germany
}

\section{Keywords}

Platelet concentrates · Bacterial screening · BactiFlow ·

Extension of shelf life

\begin{abstract}
The shelf life of platelet concentrates (PCs) was limited in Germany to 4 days after the day of production because platelet-related septic complications had been observed, mainly with PCs at the end of their shelf life. The reduction in PC shelf life gives rise to several problems, including an increased number of discarded products, accompanied by potential challenges of how to ensure an adequate supply of platelet products. The aim of this study was to show routine experience over the last 7 years using the Bactiflow (BF) assay to screen for bacterial contamination late in PC storage, followed by extension of PC shelf life.
\end{abstract}

C 2019 S. Karger AG, Basel

The limitation of platelet concentrate (PC) shelf life in Germany to 4 days (Vote 38 [1]) in order to improve blood safety poses challenges, especially for transfusion facilities which exclusively produce apheresis products [2]. Assuring an adequate platelet supply in a relatively short dating period of 4 days could result in overall reduced platelet availability [3], especially during public holidays. In Germany, a total number of 10 confirmed cases of transfusion-transmitted bacterial infections (TTBIs) have been reported from 2012 to 2015. 5 PCs were at day 4 of PC shelf life, and 1 PC was at day 3 of shelf life; the age of the remaining 4 PCs was not specified [4]. Overall, this resulted in 1.97-8.03 TTBIs (2012: 5.82 TTBIs, 2013: 3.99 TTBIs, 2014: 8.03 TTBIs, 2015: 1.97 TTBIs) per 10 Mio. PCs transfused. Therefore, bacterial contamination resulting in TTBI is a rare event, and the overall incidence of bacterially contaminated PCs is relatively low. Hence, the discard of PCs which were in fact suitable for transfusion poses ethical concerns with regard to the donor [2]. To overcome these problems, blood donation services have the option to prolong the shelf life back to 5 days if pathogen reduction or adequate bacterial detection is implemented (Vote 38 [1]). In other countries the shelf life of PCs is even further extended to 7 days after negative bacterial testing late in the PC shelf life $[5,6]$. However, in Germany this approach is often contradicted by publications questioning the remaining coagulation promoting effect of older PCs in general [7].

Some German blood donation services have implemented the rapid bacterial detection methods NAT (16S rDNA) or Bactiflow (BF) flow cytometry, combined with late sampling on day 3 or 4 of PC shelf life, followed by extension of the PC storage period to 5 days in case of negative test results $[2,8,9]$. But it is necessary to establish whether these measures will pay off in the long term. Therefore, we analyzed the age of PCs at the time of transfusion and focused on evaluation of the number of PCs transfused on day 4 of shelf life with and without bacterial testing as well as the number of PCs transfused on day 5 and PCs remaining for quality control or discard (Fig. 1).

\section{KARGER}

(C) 2019 S. Karger AG, Basel
PD Dr. Tanja Vollmer

Institut für Laboratoriums- und Transfusionsmedizin, Herz- und Diabeteszentrum Nordrhein-Westfalen

Universitätsklinik der Ruhr-Universität Bochum, Georgstrasse 11

DE-32545 Bad Oeynhausen (Germany)

E-Mail tvollmer@hdz-nrw.de 
Fig. 1. Overview of age of PCs at transfusion, proportion of PCs screened for bacterial contamination on day 4 with $\mathrm{BF}$ flow cytometry, as well as proportion of PCs with extended storage period to 5 days from 2010 to 2017. a: Age of PCs at transfusion, $\mathbf{b}$ : proportion of BF-tested PCs in relation to the total production, relation of BF-tested versus untested PCs transfused on day 4, proportion of PCs available for transfusion on day 5 after extension of PC shelf life due to negative $\mathrm{BF}$ results.

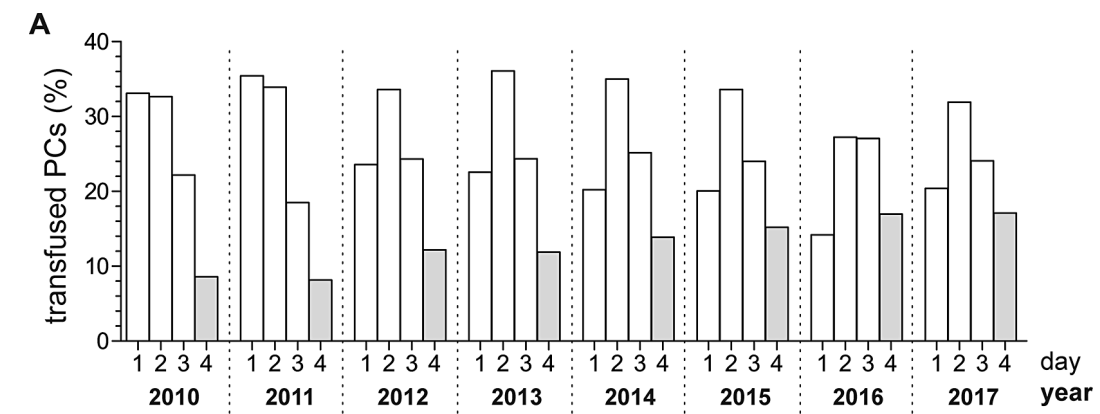

B

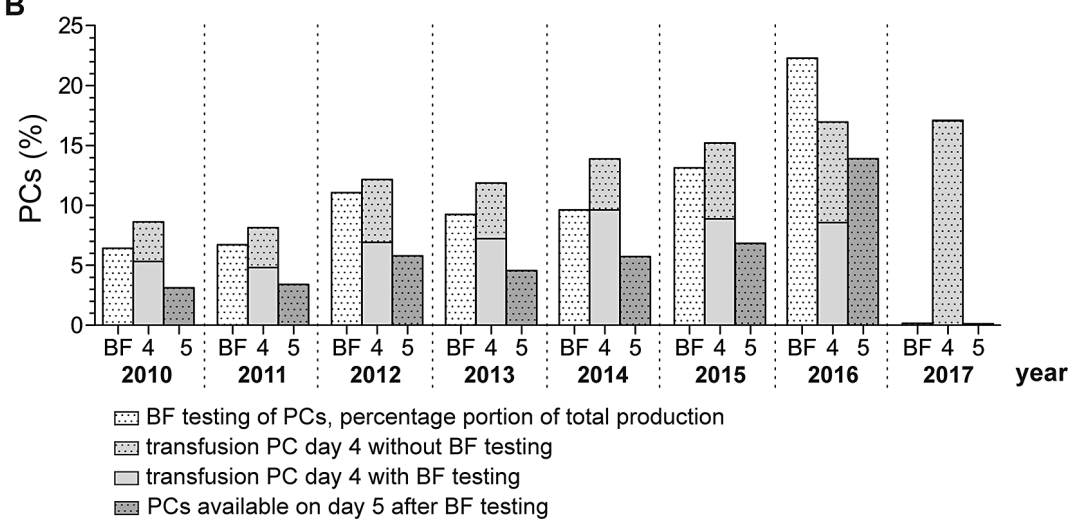

The age of apheresis PCs (APCs) (2010-2017, $n=$ $69,473,96.70 \%$ of total production) and pooled PCs (PPCs) (2015-2017, $n=2,372,3.41 \%$ of total production) at time of transfusion was investigated by year (Fig. 1a). We had a relatively uniform distribution of the age of PCs (no distinction between APCs and PPCs) at the time of transfusion over the last 7 years. In total, $2.39 \%$ of PCs were transfused on the day of donation after negative testing for viral infectious diseases (yearly minimum $\left(\mathrm{y}_{\min }\right)$ : $1.15 \%$, yearly maximum $\left.\left(\mathrm{y}_{\max }\right): 5.20 \%\right), 20.23 \%$ on day 1 of storage $\left(\mathrm{y}_{\min }: 13.05 \%, \mathrm{y}_{\max }: 30.24 \%\right), 32.96 \%$ on day 2 $\left(y_{\min }: 27.25 \%, y_{\max }: 36.09 \%\right), 24.00 \%$ on day $3\left(y_{\min }\right.$ : $\left.18.49 \%, y_{\max }: 27.06 \%\right)$, and $13.51 \%$ on day $4\left(y_{\min }: 8.14 \%\right.$, $\left.\mathrm{y}_{\max }: 17.09 \%\right)$. Therefore, approximately $80 \%$ of PCs were transfused within the first 3 days after donation. With regard to the proportion of the transfusion of untested versus bacterially tested as well as extended PCs, we also had a uniform distribution from 2010 to 2016.

The picture is a little different for the year 2017 since we were forced to suspend bacterial testing by BF in February 2017. One of the main components of the BF assay, the $\mathrm{M} 1$ reagent (naturally gained saponin from tree bark), could temporarily no longer be supplied in an adequate quality. For routine bacterial testing from 2010 to 2016, PC samples were collected on day 4 of PC shelf life at noon at the earliest, and bacterial screening by flow cytometry was performed as described previously [2]. Overall, 6.42-
$22.29 \%$ (10.13\% of total production) were tested for bacterial contamination. In total, $6.57 \%\left(y_{\min }: 4.81 \%, y_{\max }\right.$ : 9.63\%) of PCs were transfused without bacterial testing on day 4 , and $4.54 \% 3.30-8.37 \%$ of PCs were transfused after bacterial screening on day $4\left(\mathrm{y}_{\min }: 3.30, \mathrm{y}_{\max }: 8.37 \%\right.$, Fig. 1b). In total, $5.58 \%$ of PCs were available for transfusion on day $5\left(y_{\min }: 3.12, y_{\max }: 13.90 \%\right)$ after extension of PC shelf life after negative bacterial screening results on day 4 . This means that approximately $10 \%$ of transfusion recipients receiving PCs at the end of shelf life benefited from an increased safety of PCs due to bacterial screening. The omission of testing in 2017 resulted in two major drawbacks beneath the ongoing concern of achieving an adequate platelet supply: i) transfusion recipients receiving 4-day-old PCs failed to benefit from bacterial screening and ii) a considerably higher number of PCs in fact suitable for transfusion needed to be discarded. The expiration rate of PCs in years with bacterial testing and platelet storage extension was below $2 \%$ and has more than doubled in 2017, where bacterial testing was suspended.

Of all PCs screened for bacterial contamination, 6 PCs (total percentage $0.008 \%$ ) were found to be bacterially contaminated by $\mathrm{BF}$ with the following microorganisms: Staphylococcus sacharolyticus, Streptococcus dysgalactiae, Staphylococcus aureus $n=2$ [2], Streptococcus mitis $n=2$ [10]). Determined bacterial titers ranged from 1.50 to $1.19 \times 10^{7} \mathrm{CFU} / \mathrm{ml}$ and would most likely result in TTBIs. 
Therefore, this screening strategy proved to be sufficient to avoid transfusion of highly contaminated PCs at the end of shelf life. We reported no differences in reported cases of TTBIs with or without bacterial testing because no cases occurred in our transfusion facility in the respective test period.

Taking together the proportion of PCs available for transfusion on day 4 , approximately $20 \%$ had a higher risk of bacterial contamination or were in danger of expiring. Bacterial testing of 4-day-old PCs by BF lowers the risk of bacterial contamination by $4.54 \%$ on average and reduced the forfeiture rate of PCs. This means that 5.92\% of PCs in good order regarding the bacterial contamination status were further available for patients, ensuring platelet supply. The omission of bacterial testing in our transfusion facility in January 2017 sets these proportions to zero, illustrating the importance of bacterial testing. Blood donors and especially donors of PCs are not infi- nitely available, and each discarded product poses ethical concerns with regard to the donor. Alternative methods are required for the extension of PC shelf life. NAT techniques are already accepted as one potential application. However, an easier approach regarding the technical equipment and required hands-on time [11] could be the application of rapidly interpreted cultural methods-combined sampling on day 3 or 4 of PC shelf life $[9,12]$. This algorithm includes a defined minimum incubation time of sampled PCs, followed by extension of PC shelf life in case of negative results and continuous monitoring according to the negative-to-date concept.

In summary, the application of bacterial screening methods is worth the effort in order to achieve extension of platelet shelf life, combining the two advantages of enhanced platelet safety at the end of shelf life and significantly reduced discard of products which are actually in good order regarding the bacterial contamination status.

\section{References}

1 Arbeitskreis Blut. Festlegung der Haltbarkeitsfrist von Thrombozytenkonzentraten mit dem Ziel der Reduktion lebensbedrohlicher septischer Transfusionsreaktionen durch bakterielle Kontamination. Bundesgesundheitsbl Gesundheitsforsch Gesundheitsschutz. 2008;51(12):1484.

2 Vollmer T, Engemann J, Kleesiek K, Dreier J. Bacterial screening by flow cytometry offers potential for extension of platelet storage: results of 14 months of active surveillance. Transfus Med. 2011 Jun;21(3):175-82.

3 Food and Drug Administration. Bacterial risk control strategies for blood collection establishments and transfusion services to enhance the safety and availability of platelets for transfusion - draft guidance for industry. 2016. Available from: https://www.pei.de/ SharedDocs/Downloads/vigilanz/haemovigilanz/publikationen/haemovigilance-report-2015.pdf;jsessionid=7A1339AE690BD0 A 838A 8727B4572486E.1_cid319? blob $=$ publicationFile $\& v=3$
4 Funk MB, et al. Haemovigilance report of the Paul-Ehrlich-Institut 2015: Assessment of the reports of serious adverse transfusion reactions pursuant to section 63i AMG (Arzneimittelgesetz, German Medicines Act). 2017. Available from https://www.pei.de/ SharedDocs/Downloads/vigilanz/haemovigilanz/publikationen/haemovigilance-report-2015.pdf;jsessionid=7A1339AE690BD0 A 838A8727B4572486E.1_cid319?_blob $=$ publicationFile\&v $=3$

5 Prax M, Bekeredjian-Ding I, Krut O. Microbiological screening of platelet concentrates in Europe. Transfus Med Hemother. 2019;DOI 10.1159/000499349.

6 Ramirez-Arcos S, Taha M, Kou Y, Mastronardi C, Yi Q, Goldman M. Improved bacterial detection algorithm supports extension of platelet storage from 5 to 7 days at canadian blood services (p-197). Vox Sang. 2017 Jun; 112(suppl 1):134.

7 Ng MS, Tung JP, Fraser JF. Platelet storage lesions: what more do we know now? Transfus Med Rev. 2018 Apr; 32(3):S08877963(17)30189-X.
8 Müller B, Walther-Wenke G, Kalus M, Alt T, Bux J, Zeiler T, et al. Routine bacterial screening of platelet concentrates by flow cytometry and its impact on product safety and supply. Vox Sang. 2015 Apr;108(3):209-18.

9 Sireis W, Rüster B, Daiss C, Hourfar MK, Capalbo G, Pfeiffer HU, et al. Extension of platelet shelf life from 4 to 5 days by implementation of a new screening strategy in Germany. Vox Sang. 2011 Oct;101(3):191-9.

10 Vollmer T, Dreier J, Schottstedt V, Bux J, Tapernon K, Sibrowski W, et al. Detection of bacterial contamination in platelet concentrates by a sensitive flow cytometric assay (BactiFlow): a multicentre validation study. Transfus Med. 2012 Aug;22(4):262-71.

11 Störmer M, Vollmer T. Diagnostic methods for platelet bacteria screening: current status and developments. Transfus Med Hemother. 2014 Feb;41(1):19-27.

12 Vollmer T, Dabisch-Ruthe M, Weinstock M, Knabbe C, Dreier J. Late sampling for automated culture to extend the platelet shelf life to 5 days in Germany. Transfusion. 2018 Jul; 58(7):1654-64. 